\title{
Short communication: Fertility, somatic cell score, and production of Normande $\times$ Holstein, Montbéliarde $\times$ Holstein, and Scandinavian Red $\times$ Holstein crossbreds versus pure Holsteins during their first 5 lactations
}

\author{
B. J. Heins ${ }^{1}$ and L. B. Hansen \\ Department of Animal Science, University of Minnesota, St. Paul 55108
}

\begin{abstract}
Normande $(\mathrm{NO}) \times$ Holstein $(\mathrm{HO})$ crossbred cows $(\mathrm{n}$ $=251)$, Montbéliarde $(\mathrm{MO}) \times \mathrm{HO}$ crossbred cows $(\mathrm{n}$ $=503)$, and Scandinavian Red $(\mathrm{SR}) \times \mathrm{HO}$ crossbred cows $(\mathrm{n}=321)$ were compared with pure HO cows $(\mathrm{n}$ $=416$ ) for fertility, somatic cell score (SCS), and 305$\mathrm{d}$ projected milk, fat, and protein production during their first 5 lactations. The SR was a combination of Swedish Red and Norwegian Red. Cows were housed in 6 commercial herds in California and calved from June 2002 to January 2009. The NO, MO, and SR sires of crossbred cows were artificial insemination bulls via imported semen. The $\mathrm{NO} \times \mathrm{HO}, \mathrm{MO} \times \mathrm{HO}$, and $\mathrm{SR}$ $\times$ HO cows had fewer days to first breeding, enhanced first-service conception rates, higher pregnancy rates, and 12 to 26 fewer days open than did pure HO cows during their first 5 lactations. Mean SCS across lactations was similar for $\mathrm{NO} \times \mathrm{HO}(3.25)$ and pure $\mathrm{HO}$ (3.27) cows; however, $\mathrm{MO} \times \mathrm{HO}(2.98)$ and $\mathrm{SR} \times \mathrm{HO}$ (3.12) cows were significantly lower for SCS than were pure $\mathrm{HO}$ cows. The $\mathrm{MO} \times \mathrm{HO}$ cows and $\mathrm{SR} \times \mathrm{HO}$ cows were only 3 and $4 \%$ lower, respectively, than pure HO cows for 305-d projected production of fat $(\mathrm{kg})$ plus protein $(\mathrm{kg})$; however, $\mathrm{NO} \times \mathrm{HO}$ cows were $10 \%$ lower than pure $\mathrm{HO}$ cows for fat plus protein production. Therefore, the MO and SR are candidate breeds for crossbreeding with $\mathrm{HO}$ to improve the fertility and udder health of herds with high mean production.
\end{abstract}

Key words: crossbreeding, fertility, somatic cell score, production

\section{Short Communication}

The reduction of fertility of pure Holstein (HO) cows around the world has resulted in interest in crossbreeding of dairy cattle. Higher milk production, larger herd sizes, compromised cow health, and higher levels of inbreeding may have contributed to the reproduc-

Received May 10, 2011.

Accepted October 21, 2011.

${ }^{1}$ Corresponding author: hein0106@umn.edu tive decline of HO cows (Lucy, 2001). Furthermore, crossbreeding of dairy cattle has become more popular because of concerns of dairy producers regarding calf survival, cow fertility, and health of pure $\mathrm{HO}$ cows (Weigel and Barlass 2003; Funk, 2006).

The main reason for avoidance of crossbreeding in dairy cattle has been the fear of lower production of crossbreds compared with pure HO cows (Weigel and Barlass, 2003). However, Dechow et al. (2007) reported that Brown Swiss $\times \mathrm{HO}$ crossbreds had higher daily fat and protein production, with similar milk volume, compared with pure $\mathrm{HO}$ cows for first to fifth lactation. Also, Walsh et al. (2008) reported that Normande $(\mathbf{N O}) \times$ HO crossbreds had similar milk, fat, and protein production to pure HO cows, and Montbéliarde $(\mathbf{M O}) \times \mathrm{HO}$ crossbreds had similar milk and protein production to pure HO cows. Additionally, Swalve et al. (2008) concluded that Swedish Red $\times \mathrm{HO}$ and Brown Swiss $\times$ HO crossbreds had higher daily fat and protein production during first lactation than did pure HO cows.

Heins et al. (2006a) reported that $\mathrm{NO} \times \mathrm{HO}, \mathrm{MO}$ $\times \mathrm{HO}$, and Scandinavian Red $(\mathbf{S R}) \times \mathrm{HO}$ crossbreds had 3 to $7 \mathrm{~d}$ fewer mean days to first breeding (DFB) and 19 to $27 \mathrm{~d}$ fewer mean days open (DO) than did pure HO cows during the first lactation. From the same study, Heins et al. (2006b) reported that $\mathrm{SR} \times \mathrm{HO}$ cows were not significantly different from pure HO cows for 305-d projected fat plus protein production during the first lactation.

The results of Heins et al. (2006a,b) were only for first lactations of crossbred versus pure $\mathrm{HO}$ cows, and the present study compares the same crossbred and pure HO cows beyond first lactation to the fifth lactation. Specifically, the objectives of this study were to determine the differences of $\mathrm{NO} \times \mathrm{HO}, \mathrm{MO} \times \mathrm{HO}$, and $\mathrm{SR} \times \mathrm{HO}$ crossbreds versus pure HO cows in 6 commercial herds in California for fertility, udder health, and production during their first 5 lactations.

The $\mathrm{NO} \times \mathrm{HO}, \mathrm{MO} \times \mathrm{HO}, \mathrm{SR} \times \mathrm{HO}$ crossbreds, and pure HO cows calved for the first time from June 2002 to January 2005. Data for later lactations were collected on the same cows through January 2009. The 
pure $\mathrm{HO}$ cows were required to be sired by AI bulls and have a National Association of Animal Breeders (Columbia, MO) sire code in the United States. All sires for the European breed crossbreds had frozen semen imported into the United States. The SR was a combination of Norwegian Red and Swedish Red. In addition, the dams of all animals were required to be sired by an $\mathrm{HO}$ bull coded by the National Association of Animal Breeders, which permitted adjustment for the production potential of cows according to the genetic merit of their dams. This edit removed all cows from the study that had natural-service sires or maternal grandsires, because natural-service sires have unknown genetic worth.

Breeds used for crossbreeding in this study were thoroughly reviewed in Heins et al. (2006b), and the authors reported genetic levels for sires of cows and the number of daughters of each bull for this study. All cows in the study were sired by AI bulls, and the 6 California herds historically used high-ranking AI bulls from the HO breed for the Net Merit index. Among the European breeds, the AI bulls tended to rank highly within breed; however, the MO-sired cows in this study likely had a disadvantage relative to mean rank of their sires within breed (Heins et al., 2006b). The MO bulls with the most daughters in this study tended to be those with comparatively low ranking within breed for production.

One herd from the original study of Heins et al. (2006b) had only 20 cows, and the cows in that herd were excluded from this study. Hence, $251 \mathrm{NO} \times \mathrm{HO}$, $503 \mathrm{MO} \times \mathrm{HO}, 321 \mathrm{SR} \times \mathrm{HO}$, and 416 pure $\mathrm{HO}$ cows that calved for the first time were compared for fertility, SCS, and production throughout their lifetimes. The distribution of breed groups among herds is reviewed in Heins et al. (2012). The NO $\times \mathrm{HO}, \mathrm{MO} \times \mathrm{HO}, \mathrm{SR} \times$ $\mathrm{HO}$ crossbred, and pure HO cows were daughters of 24 , 23, 13, and 71 AI bulls, respectively. The 13 SR bulls were 4 Swedish Red and 9 Norwegian Red.

Calving dates, breeding dates, pregnancy diagnosis, and disposal dates were provided by the herds, and fertility traits were calculated using data from the herd management program [DairyComp 305 (Valley Agricultural Software, Tulare, CA), DHI-Plus (DHI Computing Service Inc., Provo, UT) or DairyQuest (ProfitSource LLC, Athens, WI)] used by each of the 6 herds. The DFB were calculated as the day of first service minus the calving date. The first-service conception rate (FSCR) was recorded in a binary manner as either conceived or not conceived at first service. The crossbred and pure HO cows were also compared for pregnancy rate (PR), which is the most common assessment tool for fertility of dairy herds used by veterinarians and dairy consul- tants in the United States. The PR is defined as the proportion of cows that become pregnant during a 21-d period of time; therefore, calculation of PR included cows that failed to conceive, were culled or died, or had greater DIM than the voluntary waiting period in the herd. The method of de Vries et al. (2005) was used to calculate PR.

The DO of crossbred and pure $\mathrm{HO}$ cows were measured as actual DO for cows that had a subsequent calving or had pregnancy status confirmed by a veterinarian. If no insemination was recorded, the date of conception was calculated by subtracting a mean gestation length of $280 \mathrm{~d}$ from the date of subsequent calving. To be included in the analysis for DO, crossbred and pure $\mathrm{HO}$ cows were required to have at least 250 DIM. A lower limit of $35 \mathrm{~d}$ for DO was applied, and cows with more than $250 \mathrm{~d}$ for DO had DO set to $250 \mathrm{~d}$. These minimums and maximums are used by the Animal Improvement Programs Laboratory of the USDA for routine genetic evaluations in the United States (VanRaden et. al., 2004).

The standard edits for test-day observations for SCS and production used by the USDA for routine genetic evaluation were applied in this study and were described in Heins et al. (2006b). The SCS and milk, fat, and protein production for 305-d lactations were calculated with best prediction (Cole et al., 2009). Lactational records were adjusted for age at calving, milking frequency, and previous DO, and lactations less than 305 d were projected to 305 d. To calculate SCS and 305-d projected production, best prediction was applied separately to each of the 6 herds in the study, because lactation curves may have differed for herds.

Herd-year-season of calving was based on 4-mo seasons and derived from climatic conditions in this region of California. June, July, August, and September are hot months; October, November, December, and January are rainy months; and February, March, April, and May are cool and dry months. With data spanning June 2002 to January 2009, each herd had the potential of contributing 20 year-seasons of calving. However, cows in herd-year-seasons that contained only cows from a single breed group for first lactation were eliminated from the study.

Independent variables for statistical analysis of DFB, FSCR, DO, SCS, 305-d milk, fat, protein, and fat plus protein production were effects of herd-year-season, breed group, and parity nested within breed group, along with cow nested within breed group as a random effect. Additionally, for analysis of production, a linear regression on the PTA of each cow's HO maternal grandsire was included in the models to account for the genetic level of $\mathrm{HO}$ dams of cows. The PTA for 
production traits were obtained from the January 2010 genetic evaluation of USDA via the Animal Improvement Programs website (http://aipl.arsusda.gov).

The MIXED procedure of SAS (SAS Institute, 2008) was used to obtain solutions and conduct the ANOVA; however, the GLIMMIX procedure of SAS (SAS Institute, 2008) was used to determine the statistical significance for FSCR, which is a binary trait. The LIFETEST and GLM procedure of SAS (SAS Institute, 2008) was used to evaluate statistical significance of PR for breed groups.

The data for this study included only crossbreds with HO dams and pure HO cows; therefore, heterosis could not be estimated. Consequently, differences between crossbreds and pure HO cows may be due to breed differences for additive genetic effects, heterosis from dominance effects, or a combination of the 2 effects.

Results for all traits (fertility, udder health, and production) are presented and discussed across lactations. However, a single trait for fertility (DO), for udder health (SCS), and for production (fat plus protein) will be presented and discussed by lactation to illustrate changes across the lifetimes of cows.

Table 1 has least squares means and standard errors of means for DO, and mean DO for pure HO ranged from 144 to $147 \mathrm{~d}$ from first to fourth lactation, but increased markedly to $157 \mathrm{~d}$ for the small number of pure HO that survived to the fifth lactation. During the first lactation, all of the crossbred groups had significantly $(P<0.05)$ fewer DO $(-14$ to $-21 \mathrm{~d})$ than did pure $\mathrm{HO}$ cows, and 2 to 3 wk fewer DO represents a major departure from pure $\mathrm{HO}$ cows. However, the crossbred groups differed in their change in DO across lactations. The NO $\times$ HO crossbreds had rather constant DO across lactations (123 to $132 \mathrm{~d}$ ), such that their major advantage over pure $\mathrm{HO}$ cows was for the fifth lactation. The $\mathrm{MO} \times \mathrm{HO}$ crossbreds tended to have fewer DO with advancing lactation number (131 d for the first lactation down to $110 \mathrm{~d}$ for the fifth lactation), which is contrary to universal experience with pure HO cows. The highly significant difference from pure HO cows $(47 \mathrm{~d})$ for DO in the fifth lactation was despite a higher survival rate of the $\mathrm{MO} \times \mathrm{HO}$ crossbreds to the fifth lactation. The $\mathrm{SR} \times \mathrm{HO}$ crossbreds tended to have an increase in DO with lactation so their difference from pure $\mathrm{HO}$ for DO did not change much with increasing lactation number.

In another study of data from California, first-lactation HO cows had mean DO of 155 d (Ettema and Santos, 2004), which is comparable to the DO for pure HO cows during first lactation in this study. De Vries et al. (2010) reported that DO of large confinement HO herds ranged 156 to $162 \mathrm{~d}$, which is higher than the 148-d mean for the pure HO cows in the current study. Most of the herds in the current study used synchronization programs as a reproductive aid, especially during the early years of the study; however, use of reproductive aids was not uniformly recorded within or across herds. Potentially, differences of crossbreds and pure HO cows could have been greater for DO without the aid of synchronization programs.

Inbreeding may have increased DO of pure $\mathrm{HO}$ cows in the current study, because mean inbreeding for $\mathrm{HO}$ in the United States has increased from 2.5\% in 1990 to $5.7 \%$ in 2010 (http://aipl.arsusda.gov/eval/summary/ inbrd.cfm). Conversely, heterosis may have enhanced fertility for crossbreds in the current study, because estimates of heterosis for DO were recently reported to range from 1.4 to $15.1 \%$ in the United States (Dechow et al., 2007).

Table 2 has results for SCS from first to fifth lactation for the crossbred and pure HO cows and, as expected, the pure HO cows increased in mean SCS with advancing lactation, with a low of 2.73 for the first lactation and a high of 4.02 for the fifth lactation. The $\mathrm{NO} \times \mathrm{HO}$ crossbreds were generally similar to the pure HO for SCS during the first 4 lactations but did not have the increase for SCS from the fourth to fifth lactation of the pure HO cows, resulting in significantly lower SCS for the fifth lactation. The MO $\times \mathrm{HO}$ crossbreds started lower for SCS than did the pure HO and tended to remain lower across lactations; however, the difference of 0.61 for SCC in the fifth lactation was noteworthy. Clearly, the MO $\times \mathrm{HO}$ cows were superior to the other breed groups across lactations for SCS. The SR $\times \mathrm{HO}$ crossbreds were intermediate between the $\mathrm{MO} \times \mathrm{HO}$ crossbreds and pure HO for SCS across lactations and were significantly different from pure $\mathrm{HO}$ both as young cows in first lactation and older cows in fifth lactation. The mean SCS were low in this study for all breed groups by United States standards, and the 6 herds in this study had slightly lower SCS than California herds enrolled in milk recording (California DHIA, 2009).

The PTA of the maternal grandsire was significant $(P<0.05)$ for explaining variation of only milk volume among the production traits and tended to be significant $(P=0.06)$ for fat. The solutions for linear regression of the PTA of maternal grandsire on milk, fat, protein, and fat plus protein production were $0.29 \pm$ $0.15,0.23 \pm 0.12,0.11 \pm 0.13$, and $0.18 \pm 0.14$, respectively, with expectations of 0.25 . The inclusion of PTA of maternal grandsire in statistical models should have accounted for genetic level of dams of cows for production. Dairy producers typically regard milk volume as the key measure of productivity of cows; however, most dairy producers in the United States and many other places in the world are paid for the solids in milk rather than the fluid carrier. Consequently, kilograms of solids 
Table 1. Least squares means for days open during the first 5 lactations for Normande $\times$ Holstein, Montbéliarde $\times$ Holstein, and Scandinavian Red $\times$ Holstein crossbred cows compared with pure Holstein cows

\begin{tabular}{|c|c|c|c|c|c|c|c|c|c|c|c|c|}
\hline \multirow[b]{2}{*}{ Parity } & \multicolumn{3}{|c|}{ Pure Holstein } & \multicolumn{3}{|c|}{ Normande $\times$ Holstein } & \multicolumn{3}{|c|}{ Montbéliarde $\times$ Holstein } & \multicolumn{3}{|c|}{ Scandinavian Red $\times$ Holstein } \\
\hline & $\mathrm{n}$ & Mean (d) & $\mathrm{SE}(\mathrm{d})$ & $\mathrm{n}$ & Mean (d) & $\mathrm{SE}(\mathrm{d})$ & $\mathrm{n}$ & Mean (d) & $\mathrm{SE}(\mathrm{d})$ & $\mathrm{n}$ & Mean (d) & $\mathrm{SE}(\mathrm{d})$ \\
\hline 1 & 360 & 148 & 6.2 & 232 & $127^{* *}$ & 6.1 & 477 & $131^{*}$ & 4.7 & 305 & $134^{*}$ & 5.2 \\
\hline 2 & 275 & 144 & 5.3 & 196 & $128^{*}$ & 5.7 & 396 & $120^{* *}$ & 4.3 & 254 & $133 \dagger$ & 4.9 \\
\hline 3 & 180 & 146 & 5.8 & 146 & $132 \dagger$ & 6.2 & 302 & $130 *$ & 5.0 & 181 & $132 \dagger$ & 5.8 \\
\hline 4 & 97 & 147 & 7.8 & 93 & 130 & 7.9 & 195 & $120^{* *}$ & 6.8 & 116 & 146 & 7.7 \\
\hline 5 & 37 & 157 & 12.4 & 43 & $123^{*}$ & 11.8 & 72 & $110^{* *}$ & 10.7 & 33 & 139 & 13.8 \\
\hline
\end{tabular}

$\dagger P<0.10$ for difference from pure Holsteins; ${ }^{*} P<0.05$ for difference from pure Holsteins; ${ }^{* *} P<0.01$ for difference from pure Holsteins.

Table 2. Least squares means for 305-d SCS during the first 5 lactations for Normande $\times$ Holstein, Montbéliarde $\times$ Holstein, and Scandinavian Red $\times$ Holstein crossbred cows compared with pure Holstein cows

\begin{tabular}{|c|c|c|c|c|c|c|c|c|c|c|c|c|}
\hline \multirow[b]{2}{*}{ Parity } & \multicolumn{3}{|c|}{ Pure Holstein } & \multicolumn{3}{|c|}{ Normande $\times$ Holstein } & \multicolumn{3}{|c|}{ Montbéliarde $\times$ Holstein } & \multicolumn{3}{|c|}{ Scandinavian Red $\times$ Holstein } \\
\hline & $\mathrm{n}$ & Mean & $\mathrm{SE}$ & $\mathrm{n}$ & Mean & $\mathrm{SE}$ & $\mathrm{n}$ & Mean & $\mathrm{SE}$ & $\mathrm{n}$ & Mean & $\mathrm{SE}$ \\
\hline 1 & 380 & 2.73 & 0.09 & 242 & 2.67 & 0.09 & 491 & $2.45^{* *}$ & 0.07 & 314 & $2.53^{*}$ & 0.07 \\
\hline 2 & 310 & 2.84 & 0.07 & 215 & $3.06^{*}$ & 0.07 & 432 & 2.77 & 0.06 & 269 & 2.81 & 0.06 \\
\hline 3 & 220 & 3.21 & 0.07 & 164 & 3.34 & 0.08 & 344 & $3.03 \dagger$ & 0.06 & 213 & 3.11 & 0.07 \\
\hline 4 & 127 & 3.57 & 0.09 & 121 & 3.58 & 0.09 & 247 & $3.24^{* *}$ & 0.08 & 145 & 3.48 & 0.09 \\
\hline 5 & 63 & 4.02 & 0.13 & 65 & $3.58^{* *}$ & 0.13 & 139 & $3.41^{* *}$ & 0.11 & 76 & $3.70^{*}$ & 0.13 \\
\hline
\end{tabular}


Table 3. Least squares means for 305-d projected fat plus protein production during the first 5 lactations for Normande $\times$ Holstein, Montbéliarde $\times$ Holstein, and Scandinavian Red $\times$ Holstein crossbred cows compared with pure Holstein cows

\begin{tabular}{|c|c|c|c|c|c|c|c|c|c|c|c|c|}
\hline \multirow[b]{2}{*}{ Parity } & \multicolumn{3}{|c|}{ Pure Holstein } & \multicolumn{3}{|c|}{ Normande $\times$ Holstein } & \multicolumn{3}{|c|}{ Montbéliarde $\times$ Holstein } & \multicolumn{3}{|c|}{ Scandinavian Red $\times$ Holstein } \\
\hline & $\mathrm{n}$ & Mean $(\mathrm{kg})$ & $\mathrm{SE}(\mathrm{kg})$ & $\mathrm{n}$ & Mean $(\mathrm{kg})$ & $\mathrm{SE}(\mathrm{kg})$ & $\mathrm{n}$ & Mean $(\mathrm{kg})$ & $\mathrm{SE}(\mathrm{kg})$ & $\mathrm{n}$ & Mean $(\mathrm{kg})$ & $\mathrm{SE}(\mathrm{kg})$ \\
\hline 1 & 380 & 666 & 9.8 & 242 & $619^{* *}$ & 9.3 & 491 & $644^{*}$ & 7.1 & 314 & 653 & 7.9 \\
\hline 2 & 310 & 788 & 7.7 & 215 & $706^{* *}$ & 9.3 & 432 & $750^{* *}$ & 5.9 & 269 & $756^{* *}$ & 6.8 \\
\hline & 220 & 792 & 7.6 & 164 & $713^{* *}$ & 8.1 & 344 & $765^{* *}$ & 6.4 & 213 & $759^{* *}$ & 7.4 \\
\hline 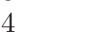 & 127 & 789 & 9.4 & 121 & $695^{* *}$ & 9.5 & 247 & $767 \dagger$ & 8.5 & 145 & $752^{* *}$ & 9.4 \\
\hline 5 & 63 & 773 & 13.5 & 65 & $703^{* *}$ & 13.3 & 139 & 763 & 11.9 & 76 & $746 \dagger$ & 7.9 \\
\hline
\end{tabular}

$\dagger P<0.10$ for difference from pure Holsteins; ${ }^{*} P<0.05$ for difference from pure Holsteins; ${ }^{* *} P<0.01$ for difference from pure Holsteins

Table 4. Least squares means for all traits across lactations for pure Holstein cows and differences of Normande $\times$ Holstein, Montbéliarde $\times$ Holstein, and Scandinavian Red $\times$ Holstein crossbred cows from pure Holstein cows $^{1}$

\begin{tabular}{|c|c|c|c|c|c|c|c|c|}
\hline \multirow[b]{2}{*}{ Trait } & \multicolumn{2}{|c|}{ Pure Holstein } & \multicolumn{2}{|c|}{ Normande $\times$ Holstein } & \multicolumn{2}{|c|}{ Montbéliarde $\times$ Holstein } & \multicolumn{2}{|c|}{ Scandinavian Red $\times$ Holsteir } \\
\hline & Mean & $\mathrm{SE}$ & $\begin{array}{c}\text { Mean } \\
\text { difference }\end{array}$ & $\mathrm{SE}$ & $\begin{array}{c}\text { Mean } \\
\text { difference }\end{array}$ & SE & $\begin{array}{c}\text { Mean } \\
\text { difference }\end{array}$ & $\mathrm{SE}$ \\
\hline Days to first breeding (d) & 70 & 0.97 & $-4^{* *}$ & 0.90 & $-7^{* *}$ & 0.74 & $-4^{* *}$ & 0.85 \\
\hline First-service conception rate (\%) & 22.6 & 0.02 & $+5.3 \dagger$ & 0.02 & $+10.1^{* *}$ & 0.02 & $+6.2^{*}$ & 0.02 \\
\hline Pregnancy rate $(\%)$ & 14.7 & 1.0 & $+4.5^{* *}$ & 1.2 & $+5.3^{* *}$ & 1.5 & $+2.8^{* *}$ & 1.0 \\
\hline Days open $(d)$ & 148 & 3.9 & $-20^{* *}$ & 3.6 & $-26^{* *}$ & 3.1 & $-12^{*}$ & 3.8 \\
\hline SCS & 3.27 & 0.05 & -0.02 & 0.05 & $-0.29^{* *}$ & 0.04 & $-0.15^{*}$ & 0.04 \\
\hline Milk volume (kg, 305-d projected) & 11,417 & 86.4 & $-1,574^{* *}$ & 83.6 & $-673^{* *}$ & 68.6 & $-790^{* *}$ & 78.4 \\
\hline Fat (kg, 305-d projected) & 409 & 3.3 & $-42^{* *}$ & 3.2 & $-12^{* *}$ & 2.6 & $-15^{* *}$ & 3.0 \\
\hline Protein (kg, 305-d projected) & 352 & 2.6 & $-32^{* *}$ & 2.5 & $-11^{* *}$ & 2.0 & $-13^{* *}$ & 2.3 \\
\hline Fat plus protein ( $\mathrm{kg}, 305-\mathrm{d}$ projected) & 762 & 5.6 & $-75^{* *}$ & 5.4 & $-24^{* *}$ & 4.4 & $-29^{* *}$ & 5.1 \\
\hline
\end{tabular}

${ }^{1}$ Least squares means for crossbred cows are presented as a difference from pure Holsteins and standard errors are for breed group means.

$\dagger P<0.10$ for difference from pure Holsteins; ${ }^{*} P<0.05$ for difference from pure Holsteins; ${ }^{*} P<0.01$ for difference from pure Holsteins 
in milk is the superior measure to assess productivity of crossbred cows compared with pure HO cows.

Fat plus protein production (Table 3 ) on a $305-\mathrm{d}$ projected basis increased dramatically (18\%) for pure HO cows from the first to second lactation, but changed very little from the second to fourth lactation and decreased $16 \mathrm{~kg}$ from the fourth to fifth lactation. The $\mathrm{NO} \times \mathrm{HO}$ cows were significantly $(P<0.01)$ lower than pure $\mathrm{HO}$ cows for fat plus protein production during all lactations. However, the $\mathrm{MO} \times \mathrm{HO}$ cows were significantly $(P<0.05)$ lower than pure HO cows for fat plus protein production from the first to third lactation, but the difference from pure HO cows was only $22 \mathrm{~kg}$ in the fourth lactation and $10 \mathrm{~kg}$ in the fifth lactation, and these differences were not statistically significant. The $\mathrm{SR} \times \mathrm{HO}$ cows were not significantly different from pure $\mathrm{HO}$ cows for fat plus protein production during the first lactation; however, the difference from pure HO cows was significant $(P<0.01)$ for the second to fourth lactation $(-32$ to $-37 \mathrm{~kg})$. For the fifth lactation, $\mathrm{SR} \times \mathrm{HO}$ cows only tended $(P<0.10)$ to be lower than pure HO cows for fat plus protein production.

Results across lactations are in Table 4 and the least squares means for the crossbred groups are presented as differences from the pure HO cows. The 3 crossbred groups were all consistently superior to the pure HO cows for fertility. Advantages for fertility of the crossbred cows compared with pure HO cows may have been partially due to the decreased calving difficulty and stillbirths observed for the crossbred cows (Heins et al. 2006c). Also, the NO and MO breeds in France have selected for body condition along with production over time. The extra body condition provided by these 2 breeds may explain the outstanding performance for fertility compared with pure $\mathrm{HO}$ cows in this study. The $\mathrm{SR} \times \mathrm{HO}$ cows also had significant advantages over the pure HO cows for all of the fertility traits, and both SR breeds have included female fertility in their selection programs alongside production for many years. The fertility results for $\mathrm{MO} \times \mathrm{HO}$ cows compared with pure HO cows were striking for FSCR (33 versus 23\%), PR (20 versus $15 \%$ ), and DO (122 versus $148 \mathrm{~d}$ ).

The DFB of pure HO cows in this study $(70 \mathrm{~d})$ are fewer than reported by Norman et al. (2009) for the entire United States dairy herds ( $86 \mathrm{~d}$ ). However, Weigel and Rekaya (2000) reported similar results of 71 $\mathrm{d}$ for DFB of pure HO cows in California. The pure HO cows in the current study had slightly lower FSCR than those in the study of Ettema and Santos (2004), who reported FSCR of 25 to $42 \%$ across various calving seasons for pure $\mathrm{HO}$ cows in California.

Across lactations, the $\mathrm{NO} \times \mathrm{HO}$ crossbreds (3.25) were similar to pure HO cows (3.27) for mean SCS. On the other hand, the advantages of crossbreds for fertility in this study were coupled with reductions of $\mathrm{SCS}$ for the MO $\times \mathrm{HO}(2.98)$ and $\mathrm{SR} \times \mathrm{HO}(3.12)$ crossbreds compared with the pure HO cows (3.27) that were impressive and significant.

Milk volume of the pure HO cows $(11,417 \mathrm{~kg})$ in this study across lactations on a 305-d projected basis is higher than the mean milk volume for California HO cows (California DHIA, 2009); however, the means for $305-\mathrm{d}$ projected fat and protein production of pure $\mathrm{HO}$ cows (409 and $352 \mathrm{~kg}$, respectively) in the current study are similar to the mean of $\mathrm{HO}$ cows on milk recording in California. The means for fat plus protein production across lactations on a $305-\mathrm{d}$ projected basis were significantly $(P<0.01)$ lower for $\mathrm{NO} \times \mathrm{HO}(687 \mathrm{~kg})$, $\mathrm{MO} \times \mathrm{HO}(738 \mathrm{~kg})$, and $\mathrm{SR} \times \mathrm{HO}(733 \mathrm{~kg})$ crossbreds compared with the pure HO cows $(762 \mathrm{~kg})$. The mean difference across lactations from pure $\mathrm{HO}$ cows for fat plus protein production was $75 \mathrm{~kg}$ for the $\mathrm{NO} \times \mathrm{HO}$ cows, but only 24 and $29 \mathrm{~kg}$ for the $\mathrm{MO} \times \mathrm{HO}$ and $\mathrm{SR}$ $\times$ HO crossbreds, respectively. On a percentage basis across the first 5 lactations, the $\mathrm{NO} \times \mathrm{HO}$ crossbreds were $10 \%$ lower; however, the $\mathrm{MO} \times \mathrm{HO}$ and $\mathrm{SR} \times \mathrm{HO}$ crossbreds were only 3 and $4 \%$ lower, respectively, for fat plus protein production than were pure HO cows.

Importantly, the results for production are reported on a 305-d projected basis, which does not necessarily reflect milk produced within a fixed interval of time (say, 12 mo), because cows that died or left the herd are projected to 305 d. Furthermore, all of the crossbred groups had superior means for fertility; therefore, the crossbreds returned to peak production in subsequent lactations sooner than their pure $\mathrm{HO}$ contemporaries. The means of breed groups for 305-d projected production were not adjusted for differences in current DO for cows, and the crossbred groups had 12 to $26 \mathrm{~d}$ fewer DO than pure HO cows in this study. The DO in current lactation affects 305-d production (Bohmanova et al., 2009; Loker et al., 2009); however, appropriate adjustment of production for current DO is difficult, because the cause-and-effect association of production and DO is not easily unraveled. Adjustment for breed group differences for current DO may have brought the production of crossbred cows even closer to the production of pure $\mathrm{HO}$ cows.

The means for fat percentage across the 5 lactations were $+0.15 \%$ for $\mathrm{NO} \times \mathrm{HO},+0.11 \%$ for $\mathrm{MO} \times \mathrm{HO}$, and $+0.13 \%$ for $\mathrm{SR} \times \mathrm{HO}$ crossbreds compared with the pure HO cows $(3.58 \%)$. Similarly, the means for protein percentage were $+0.17 \%$ for $\mathrm{NO} \times \mathrm{HO},+0.09 \%$ for $\mathrm{MO} \times \mathrm{HO}$, and $+0.11 \%$ for $\mathrm{SR} \times \mathrm{HO}$ crossbreds compared with the pure HO cows $(3.08 \%)$.

Mean production of pure Swedish Red versus pure $\mathrm{HO}$ cows in Sweden suggests that the production of the $\mathrm{SR} \times \mathrm{HO}$ cows in this study should have been very near 
the production of pure HO cows, even if little heterosis for production was assumed. Perhaps, heterosis for fat plus protein production of $\mathrm{SR} \times \mathrm{HO}$ cows is small because the SR and HO breeds share distant ancestry. Also, the Norwegian Red breed has a meaningful amount of HO-Friesian content, which could reduce heterosis in crosses with $\mathrm{HO}$. On the other hand, MO and $\mathrm{HO}$ are genetically very distant breeds; therefore, crosses of those 2 breeds may express substantial heterosis, because Mäki-Tanila (2007) indicated heterosis increases as the genetic distance between breeds becomes greater.

Crossbreeding of dairy cattle is being explored mostly for its potential to improve the calving ease, fertility, health, and survival of cows. Advantages for these functional traits will compensate substantially for any potential loss of production of crossbreds compared with pure HO cows. Production and functional traits must be assessed collectively to gauge the total economic merit of dairy cows. Increasingly, dairy producers, consultants, extension educators, and industry leaders should measure dairy cow performance in a more comprehensive way instead of by milk production alone.

\section{REFERENCES}

Bohmanova, J., J. Jamrozik, and F. Miglior. 2009. Effect of pregnancy on production traits of Canadian Holstein cows. J. Dairy Sci. 92:2947-2959.

California DHIA. 2009. 2009 Annual Production Summary. Accessed July 25, 2010. http://www.cdhia.org/Annual_Summaries/2009 ALL HERD Summary Vertical.pdf.

Cole, J. B., D. J. Null, and P. M. VanRaden. 2009. Best prediction of yields for long lactations. J. Dairy Sci. 92:1796-1810.

Dechow, C. D., G. W. Rogers, J. B. Cooper, M. I. Phelps, and A. L. Mosholder. 2007. Milk, fat, protein, somatic cell score, and days open among Holstein, Brown Swiss, and their crosses. J. Dairy Sci. 90:3542-3549.

De Vries, A., J. D. Olson, and P. J. Pinedo. 2010. Reproductive risk factors for culling and productive life in large dairy herds in the eastern United States between 2001 and 2006. J. Dairy Sci. 93:613-623.

de Vries, A., C. Steenholdt, and C. A. Risco. 2005. Pregnancy rates and milk production in natural service and artificially inseminated dairy herds in Florida and Georgia. J. Dairy Sci. 88:948-956.
Ettema, J. F., and J. E. P. Santos. 2004. Impact of age at calving on lactation, reproductive, health, and income in first-parity Holsteins on commercial farms. J. Dairy Sci. 87:2730-2742.

Funk, D. A. 2006. Major advances in globalization and consolidation of the artificial insemination industry. J. Dairy Sci. 89:1362-1368.

Heins, B. J., L. B. Hansen, and A. De Vries. 2012. Survival, lifetime production, and profitability of Normande $\times$ Holstein, Montbéliarde $\times$ Holstein, and Scandinavian Red $\times$ Holstein crossbreds versus pure Holsteins. J. Dairy Sci. 95:1011-1021. doi:10.3168/ jds.2011-4525.

Heins, B. J., L. B. Hansen, and A. J. Seykora. 2006a. Fertility and survival of pure Holsteins versus crossbreds of Holstein with Normande, Montbeliarde, and Scandinavian Red. J. Dairy Sci. 89:4944-4951.

Heins, B. J., L. B. Hansen, and A. J. Seykora. 2006b. Production of pure Holsteins versus crossbreds of Holstein with Normande, Montbeliarde, and Scandinavian Red. J. Dairy Sci. 89:2799-2804.

Heins, B. J., L. B. Hansen, and A. J. Seykora. 2006c. Calving difficulty and stillbirths of pure Holsteins versus crossbreds of Holstein with Normande, Montbeliarde, and Scandinavian Red. J. Dairy Sci. 89:2805-2810.

Loker, S., F. Miglior, J. Bohmanova, J. Jamrozik, and L. R. Schaeffer. 2009. Phenotypic analysis of pregnancy effect on milk, fat, and protein yields of Canadian Ayrshire, Jersey, Brown Swiss, and Guernsey breeds. J. Dairy Sci. 92:1300-1312.

Lucy, M. C. 2001. Reproductive loss in high-producing dairy cattle: Where will it all end? J. Dairy Sci. 84:1277-1293.

Mäki-Tanila, A. 2007. An overview on quantitative and genomic tools for utilising dominance genetic variation in improving animal production. Agric. Food Sci. 16:188-198.

Norman, H. D., J. R. Wright, S. M. Hubbard, R. H. Miller, and J. L. Hutchison. 2009. Reproductive status of Holstein and Jersey cows in the United States. J. Dairy Sci. 92:3517-3528.

SAS Institute. 2008. SAS/STAT Software. Release 9.2. SAS Inst. Inc. Cary, NC.

Swalve, H. H., N. Bergk, and P. H. Solms-Lich. 2008. Kreuzungszucht beim Milchrind-Ergebnisse aus einem Prazisbetrieb. Züchtungskunde 80:429-442.

VanRaden, P. M., A. H. Sanders, M. E. Tooker, R. H. Miller, H. D. Norman, M. T. Kuhn, and G. R. Wiggans. 2004. Development of a national genetic evaluation for cow fertility. J. Dairy Sci. $87: 2285-2292$.

Walsh, S., F. Buckley, K. Pierce, N. Byrne, J. Patton, and P. Dillon. 2008. Effects of breed and feeding system on milk production body weight, body condition score, reproductive performance, and postpartum ovarian function. J. Dairy Sci. 91:4401-4413.

Weigel, K. A., and K. A. Barlass. 2003. Results of a producer survey regarding crossbreeding on US dairy farms. J. Dairy Sci. $86: 4148-4154$

Weigel, K. A., and R. Rekaya. 2000. Genetic parameters for reproductive traits of Holstein cattle in California and Minnesota. J. Dairy Sci. 83:1072-1080. 